\title{
Scholars and Literati at the University of Pont-à-Mousson (1572-1768)
}

\author{
David de la Croix Soraya Karioun \\ IRES/LIDAM, UCLouvain
}

This note is a summary description of the set of scholars and literati who taught at the Jesuit University of Pont-à-Mousson from its inception in 1572 to its transfer to Nancy in 1768.

\section{The UnIVERsity}

The University of Pont-à-Mousson was a Jesuit institution founded in 1572 by Pope Gregory XIII, at the instigation of Cardinal Charles I of Lorraine and Duke Charles III. With a direction entrusted exclusively to the Jesuits, the University contributed to the influence and expansion of the religious order in the region and was a powerful instrument of the Counter-Reformation. In 1768, the University did not escape from the banishment of the Jesuits from France and was therefore closed and transferred to the University of Nancy (see Martin (1891) and Guénée (1981)).

\section{SOURCES}

Eugène Martin (1859 - 1948), Doctor of Letters and Prelate of the Diocese of Nancy, is the author of "L'Université de Pont-à-Mousson (1572 - 1768)" (Martin 1891). The book focuses on the history of the University from its establishment to its closure, but also describes the internal organization, and the student and teacher bodies. In addition to this main source, the "Bibliothèque de la Compagnie de Jésus" by Carlos Sommervogel (1890) offers an extensive catalogue with biographical references to the Jesuits.

\section{SOME STATistics}

Table 1 shows some descriptive statistics. There are 459 scholars and literati. The year of birth is known for $26 \%$ of them. The mean age at appointment is 32 years. The expected age at death when 30 is of 68 years on a average, with a drop in the last period. The birth place is known for $24.6 \%$ of the individuals, which indicates that many in our list drawn from (Martin 1891) could not be matched with entries in biographical dictionaries. The median distance between birth and Pont-à-Mousson is $152 \mathrm{~km}$. It is higher in the first period when the university had to attract more people from far away to populate its faculty and start its activity. Finally, $5.9 \%$ of the scholars have a Wikipedia page (in some language), and $17.4 \%$ of them have left a footprint in the catalogues of the libraries of the world, Worldcat, either by having published some work, or by having been the subject of published books and articles. The difference between these two numbers indicates that, for Jesuits, it was important to write and publish books, even for people who would remain quite obscure.

\section{FIELDS}

Figure 1 shows the relative importance of fields, broadly defined. In order to preserve and promote the Catholic faith, as well as to train students in the fundamentals of humanism, the University of Pont-à-Mousson was initially constituted of two faculties: the Faculty of Theology and the Faculty of Philosophy. It was only later and with some reluctance that the Faculty of Law and the Faculty 
of Medicine were established. Being secular, the latter did not develop successfully as, in the eyes of the founders, it represented a threat and an obstacle to the initial project (Martin 1891). This is what can be seen in the pie chart.

\begin{tabular}{|c|c|c|c|c|c|c|}
\hline \multicolumn{2}{|c|}{ Period } & $\mathrm{nb}$. & \% birth year & mean age & mean age & exp. age \\
\hline Start & End & obs & known & at appoint. & at death & at death \\
\hline 1527 & 1617 & 98 & 43.9 & 30.0 & 64.1 & 65.5 \\
\hline 1618 & 1685 & 142 & 23.2 & 34.2 & 69.5 & 69.9 \\
\hline 1686 & 1733 & 139 & 20.1 & 34.4 & 72.8 & 72.7 \\
\hline 1734 & 1800 & 80 & 20 & 29.1 & 65.8 & 67.2 \\
\hline 1000 & 1800 & 459 & $\overline{2} \overline{1} \overline{1}$ & 32.0 & $6 \overline{7.9}$ & 68.0 \\
\hline & & & $\begin{array}{c}\text { \% birth place } \\
\text { known }\end{array}$ & $\begin{array}{l}\text { median distance } \\
\text { birth-institution }\end{array}$ & $\begin{array}{c}\% \text { with } \\
\text { Wikipedia }\end{array}$ & $\begin{array}{c}\% \text { with } \\
\text { Worldcat }\end{array}$ \\
\hline 1527 & 1617 & & 40.8 & 272 & 17.3 & 30.6 \\
\hline 1618 & 1685 & & 21.8 & 121 & 2.8 & 13.4 \\
\hline 1686 & 1733 & & 20.1 & 91 & 2.2 & 15.8 \\
\hline 1734 & 1800 & & 17.5 & 111 & 3.8 & 11.2 \\
\hline 1000 & 1800 & & $\overline{2} \overline{4} . \overline{6}$ & 152 & 5.9 & 17.4 \\
\hline
\end{tabular}

Table 1: Summary statistics by period

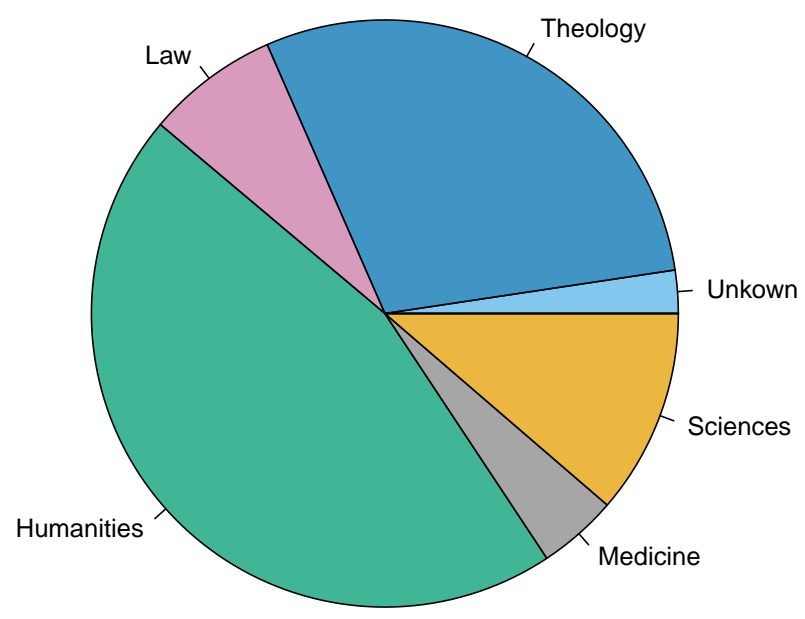

Figure 1: Broad fields at Pont-à-Mousson

\section{Place of Birth}

Figure 2 is a plot of the places of birth of all the scholars of Pont-à-Mousson, and shows very clearly how the basin of attraction of the University shrunk over time. In the period 1537-1617, many scholars came from the South West of France, and from England and Scotland (Catholics fleeing the Reformation). Places of birth became more and more concentrated around Pont-à-Mousson in the subsequent periods. 


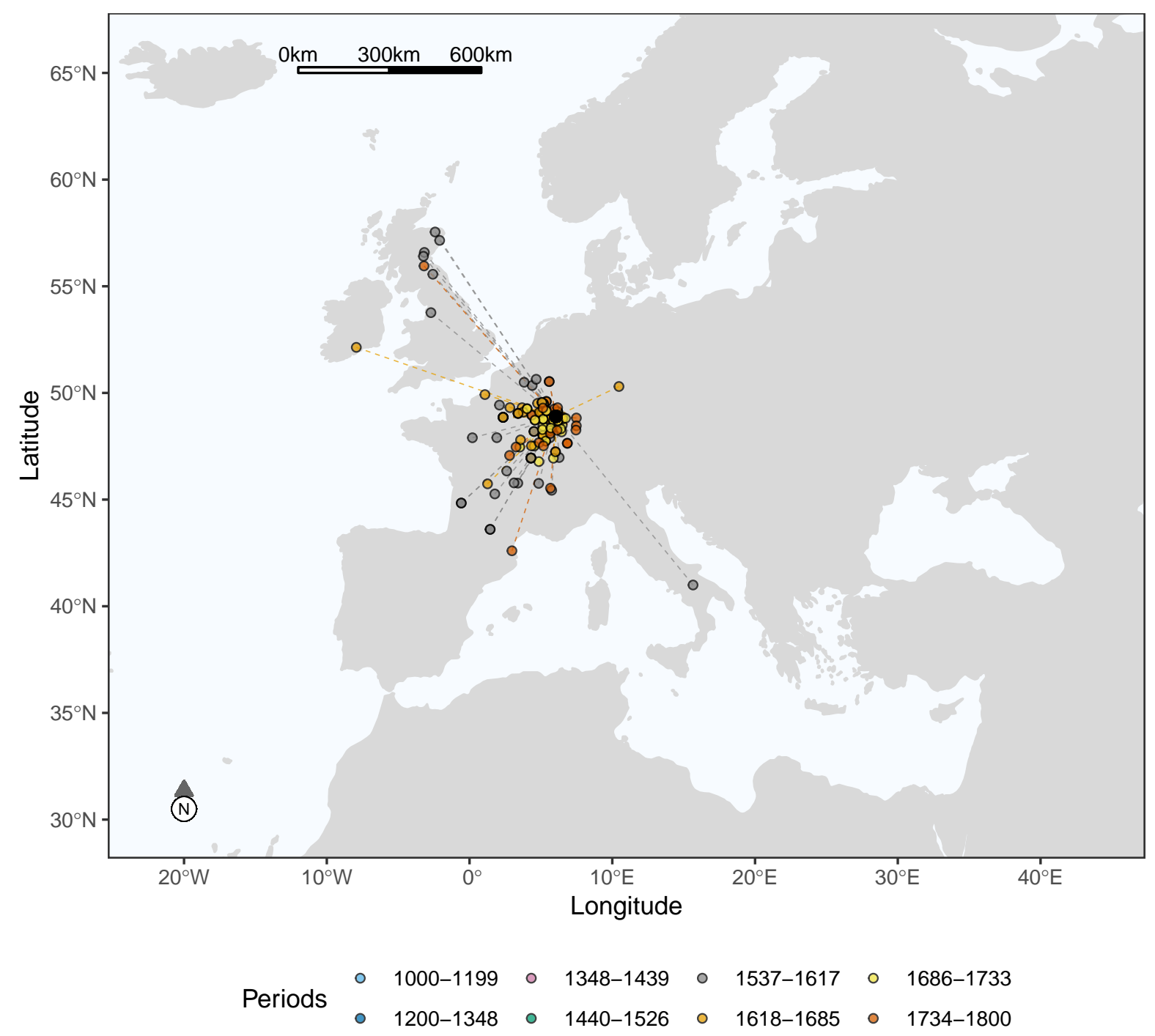

Figure 2: Place of birth of the scholars and literati at the University of Pont-à-Mousson

\section{HUMAN CAPITAL OF SCHOLARS AND LITERATI}

For each person in the database we compute a heuristic human capital index, identified by combining information from Worldcat and Wikipedia using a principal component analysis. We also compute the notability of the university at each date by averaging the human capital of the scholars active in Pont-à-Mousson 25 years before that date. Details are given in the Appendix. Figure 3 shows the names of all the scholars with a positive human capital index. The orange line plots the notability of the university. The vertical green lines (rug plot) show the distribution of all scholars, including the obscure ones, over time. The pattern is that of a rise in the quality of the scholars and literati of the University to a high level around 1640-1670 - all the top scholars were active before or during these years - and then a slow decline with some rebounds.

\section{TOP 6 PROFESSORS}

We now provide a brief overview of the six professors with the highest human capital index. 


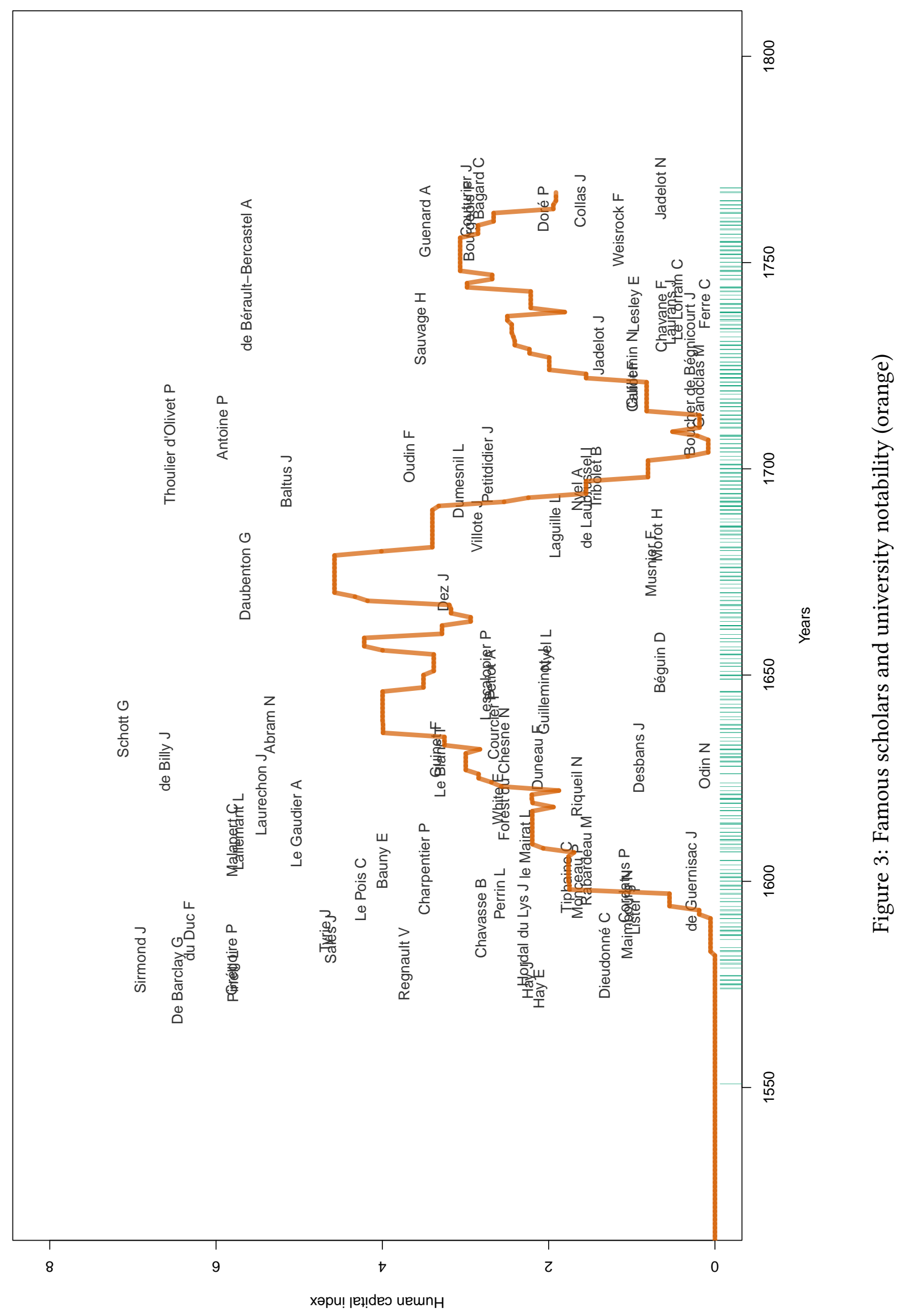


Jacques Sirmond (Riom 1559 -- Paris 1651) was known as one of the most erudite Jesuits of his time. He thoroughly studied ancient languages at Pont-à-Mousson, where he then taught for a year. After teaching rhetoric in Paris, he moved to Rome in 1590, and worked as a secretary to the Superior General of the Society of Jesus, Claudio Acquaviva, for 18 years. Back in France in 1608, he became King Louis XIII's confessor.

Gaspar Schott (Königshofen 1607 -- Würzburg 1666) was a man of both religion and science. Ordained a priest in 1637, he taught mathematics at Pont-à-Mousson the same year. He then taught theology, philosophy, and mathematics at Palermo for twenty years. Considered a brilliant and universal mind, his work as a scientist on hydraulic and mechanical instruments has remained renowned and valuable.

Jacques de Billy (Compiègne 1602 -- Dijon 1679) was a mathematician, as well as a professor and rector at several institutions, including the University of Pont-à-Mousson in 1629. His work led to significant advances in several fields of science, such as number theory and the constitution of astronomical tables. The Billy Crater on the Moon is named after him.

Pierre Joseph Thoulier d'Olivet (Salins-les-Bains 1682 - Paris 1768) was a grammarian and translator, member of the Académie Française (1723). He participated actively to the dictionary of the academy. We find his name in Martin (1891) as a professor of rhetoric at the University of Pont-à-Mousson in 1706. He left the Jesuits soon after, preferring his freedom and an obscure life, totally devoted to research (Michaud 1811).

Guillaume de Barclay (Aberdeen 1546 -- Angers 1608) was a Scottish jurist, who graduated from the University of Aberdeen. He went to the University of Bourges in 1573, where he studied and taught. He was the author of an abundant literature and one of the first law professors at the newly inaugurated University of Pont-à-Mousson, a position he held for twenty-five years.

Fronton du Duc (Bordeaux 1558 -- Paris 1624) was a master of many disciplines, and distinguished himself mainly by his knowledge of Greek and his studies of ancient texts. He taught theology and rhetoric for many years at Pont-à-Mousson, but also at Bordeaux and at the Collège of Clermont (Paris). He is known as one of the most illustrious playwrights of the Company, notably for composing the tragedy on Joan of Arc's ordeal, L'histoire tragique de la Pucelle d'Orléans, in 1580.

\section{UNIVERSITY NETWORK}

Here we assume that when a professor occupied a position at more than one university over his/her life, this established a link between those universities. The universities with which Pont-à-Mousson is linked are displayed in Figure 4. Again, many links can be observed in the first period and very few afterwards. The Jesuits were used to often reallocating their scholars among the numerous universities that they created in Europe.

\section{APPENDIX}

The individual human capital index $q_{i}$ of an individual $i$ is given by:

$$
\begin{aligned}
q_{i}= & -1.76+0.43 \ln (\mathrm{nb} . \text { characters of the longest Wikipedia page }) \\
& +0.40 \ln (\mathrm{nb} . \text { wikipedia pages in different languages })+0.47 \ln (\text { nb. works in Worldcat }) \\
& +0.46 \ln (\text { nb. publication languages in Worldcat })+0.47 \ln (\mathrm{nb} \text {. library holdings in Worldcat })
\end{aligned}
$$

We assume that having no Wikipedia page is similar to having one page with a length of 60 characters and that having no Worldcat page is similar to having a page with one work in one language held by one library. The constant -1.76 normalizes $q_{i}$ at 0 when there is neither a Wikipedia page, 


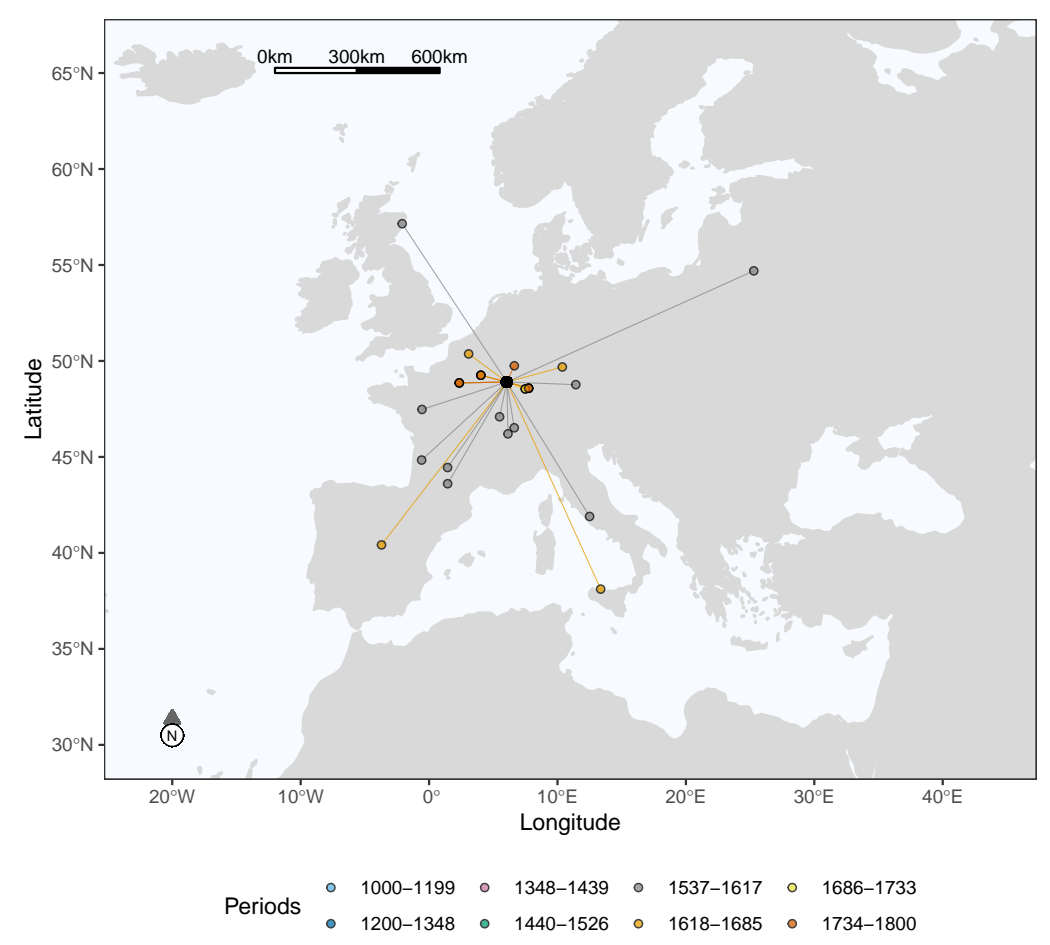

Figure 4: Links between Pont-à-Mousson and other universities through scholars' mobility, by period

nor a Worldcat page. The weights $(0.43,0.40$, etc) are obtained from the first principal component of the five indicators (De la Croix et al. 2020). The notability $Q$ of a university aggregates the $q$ of the top 5 persons who were active in the preceding 25 years using the following formula:

$$
Q=\sqrt{\sum_{i=1}^{5} \frac{1}{5}\left(\frac{q_{i}}{s_{i}}\right)^{2}}
$$

where $s_{i}$ is the number of universities in which $i$ had an appointment.

\section{ACKNOWLEDGMENTS}

This project has received funding from the European Research Council (ERC) under the European Union's Horizon 2020 research and innovation programme, under grant agreement No 883033 "Did elite human capital trigger the rise of the West? Insights from a new database of European scholars."

First version January 5, 2021. Updated September 29, 2021

\section{REFERENCES}

De la Croix, David, Frédéric Docquier, Alice Fabre, and Robert Stelter. 2020. "The Academic Market and the Rise of Universities in Medieval and Early Modern Europe (1000-1800).” CEPR Discussion Paper 14509.

Guénée, Simone. 1981. Bibliographie des universités françaises des origines à la Révolution, Généralités-Université de Paris, 1981. Paris: Picard.

Martin, Eugène. 1891. L'Université de Pont-à-Mousson (1572-1768). Paris-Nancy: Berger-Levrault.

Michaud, Joseph-François. 1811. Biographie universelle ancienne et moderne, 45 vols. Paris: Bureau de la Biographie Universelle.

Sommervogel, Carlos. 1890. Bibliothèque de la Compagnie de fésus. Brussels: Oscar Schepens. 